\title{
Kolaborasi Pencegahan Dan Penanggulangan Covid-19 Di Kota Baubau
}

\author{
Zainul Abidin ${ }^{1}$, Nurhayati ${ }^{2}$, La Didi $^{3}$, Suharny $^{4}$ \\ ${ }^{1234}$ Universitas Dayanu Ikhsanuddin \\ 1 zainulabidin180@gmail.com
}

\begin{tabular}{l}
\hline Keywords: \\
\hline Collaboration, \\
Prevention, \\
Countermeasurs, \\
Covid-19, \\
Tangguh Village \\
\hline
\end{tabular}

Kata Kunci:

Kolaborasi,

Pencegahan,

Penanggulangan,

Covid-19,

Kampung

Tangguh

\begin{abstract}
This study aims to describe the collaboration for the prevention and control of COVID-19 in Baubau City. This research is important because there are problems in the dynamics of collaboration, especially related to maintenance, as well as to describe the uniqueness that occurs. The research design used was qualitative with a descriptive approach. Data collection techniques using observation, interviews, and documents. The data analysis technique uses an interactive model. The results of the study show that community-based collaboration has been implemented, especially in Wajo and Lakologou Villages through the construction of tough villages by having order and security toughness, information resilience, psychological toughness and cultural toughness. There is also maintenance or system maintenance. However, the maintenance or maintenance of tough villages in Lakologou Village has stronger characteristics and has more potential for sustainability. The collaboration that occurs is able to bring in new contributors, social capital and condition sustainability. A tough village with its various tools should be maintained and even improved for other interests in the future.
\end{abstract}

Abstrak
Penelitian ini bertujuan menguraikan kolaborasi pencegahan dan
penanggulangan covid 19 di Kota Baubau. Penelitian ini penting
karena adanya masalah dalam dinamika kolaborasi, khususnya
berkaitan pemeliharaan, disamping untuk menguraikan
keunikan yang terjadi. Desain penelitian yang digunakan
kualitatif dengan pendekatan deskriptif. Teknik pengumpulan
data menggunakan observasi, wawancara, dan dokumen. Teknik
analisis data menggunakan model interaktif. Hasil penelitian
menunjukkan Kolaborasi berbasis masyarakat sudah
dilaksanakan khususnya di Kelurahan Wajo dan Lakologou
melalui pembangunan kampung tangguh dengan memiliki
ketangguhan ketertiban dan keamanan, ketangguhan informasi,
ketangguhan psikologi dan ketangguhan budaya. Terdapat pula


pemeliharaan atau sistem maintenance. Namun Pemeliharaan atau maintenance kampong tangguh yang ada di Kelurahan Lakologou memiliki karakteristik yang lebih kuat dan lebih memiliki potensi keberlanjutan. Kolaborasi yang terjadi mampu menghadirkan kontributor baru, modal sosial dan mengkondisikan keberlanjutan. Kampung tangguh dengan berbagai perangkatnya semestinya diperthankan bahkan ditingkatkan bagi kepentingan - kepentingan lain ke depan.

\section{Pendahuluan}

Di Kota Baubau. dalam pencegahan dan penanganan covid-19, beberapa kelurahan melakukan beberapa upaya yang salah satunya dengan membangun kampung tangguh. Menurut Undang-Undang Nomor 36 Tahun 2009 tentang kesehatan, kampung tangguh merupakan upaya pemerintah agar melakukan pencegahan penyakit. Upaya kesehatan tersebut merupakan rangkaian aktivitas yang dilakukan secara terpadu dengan maksud memelihara derajat kesehatan masyarakat (Setneg, 2009). Pembangunan kampung tangguh juga memiliki alasan kuat karena sebagaimana diketahui secara hukum satgas Covid-19 terendah secara formal keberadaan dan fungsinya masih sangat kurang pada tingkat kelurahan atau komunitas. Prinsip kerja kampung tangguh menyerupai sistem android dimana semakin banyak ketanggunan, maka semakin tangguh. Ketangguhan dalam mencegah dan menanggulangi covid tentunya didasarkan pada kolaborasi antara pemangku kepentingan yang ada.

Kolaborasi saat ini telah menjadi arus utama dalam manajemen pembangunan dan pelayanan publik. Alasan pertamanya adalah mendorong demokratisasi pembangunan. Kedua, menghindari memubazirkan sumberdaya. Dengan kolaborasi juga dapat memudahkan perwujudan good governance dimana menuntut keterlibatan berbagai pihak. Dengan variasi asal-usul, implementasi pembangunan dapat melibatkan sumberdaya, organisasi dan norma-norma yang beragam (Salman, 2004). Rachim (2020) mengatakan dalam perspektif administrasi publik, kolaborasi adalah kerja secara bersama beberapa pihak dalam suatu kegiatan untuk mencapai tujuan. Hal ini tentu koheren dengan pengertian dari administrasi yang merupakan kerja sama antara dua orang atau lebih untuk mencapai tujuan. Posisi kolaborasi dalam literatur administrasi publik sering digunakan terminologi governance untuk menjelaskan keterkaitan antar organisasi (Ansell, C., \& Gash, 2008). 
Namun, pengertian governance bukan sekadar pelibatan tetapi koneksivitas berbagai lembaga untuk melaksanakan kehendak publik. Kolaborasi memfasilitasi multi organisasi memecahkan masalah yang tidak bisa dipecahkan sendirian (Sudarmo, 2015). Tujuan utama dalam kolaborasi sector publik diperuntukkan pada peningkatan pelayanan pada masyarakat (Haryono, 2012).

Namun, temuan di lapangan terdapat masalah dalam pelaksanaan kampung tangguh. Di Kota Baubau. Di Kelurahan Wajo yang merupakan pemenang lomba dari program kampung tangguh yang dilaksanakan Kepolisian resort Kota Baubau, tampak posko tim relawan, lumbung tani, bantuan sosial dan fasilitas dan alat-alat yang digunakan untuk penanganan Covid-19 tidak lagi ditemukan. Terkesan keberadaan kampung tangguh yang ada hanya diperuntukkan untuk perlombaan. Namun ini berbeda dengan pengamatan di Kelurahan Lakologu, masih didapatkan berbagai informasi program kampung tangguh, bahkan dokumentasi terkait pencegahan dan penganganan Covid-19 masih tersimpan, tempat posko dan lokasi lumbung tani masih ada sampai sekarang.

Hasil penelitian terdahulu yang terkait kolaborasi penanggulangan Covid-19 antara lain dilakukan Andriyani (2020) yang menyimpulkan modal sosial masih berkembang serta jejaring yang dibangun menjadi instrumen penting kesuksesan program. Modal sosial yang bersumber dari banyak organisasi yang ada dikelola sebagai aset. Penelitian selanjutnya oleh Ni Made Dwi Arisanti (2020) yang menunjukkan bahwa dalam penanganan pandemi Covid-19, Pemerintah Kabupaten Gianyar berkolaborasi bersama ormas lokal yaitu KNPI Gianyar dimana kolaborasi ini memanfaatkan teknologi informasi yang berwujud aplikasi Karina, dan juga pendekatan dengan kearifan lokal menyama braya (gotong royong) dengan membentuk Satgas Pemuda Perangi Covid-19. Respons masyarakat Gianyar terhadap aplikasi Karina sangat baik karena dan efektif menghadapi pandemi Covid-19.

Kedua penelitian ini mengindikasikan pentingnya kolaborasi dalam penanggulangan covid 19, baik melalui modal sosial, jejaring, kearifan lokal maupun penggunaan teknologi informasi. Kolaborasi mampu menciptakan kekuatan baru dan dapat membantu penanganan covid- 19. Kedua penelitian itu juga menunjukkan bahwa setiap tempat memiliki cara sendiri dalam mengatasi masalah dengan sumberdaya yang dimiliki (sumberdaya, organisasi dan nilai serta norma masing - masing) Olehkarena itu, penelitian tentang kolaborasi di tingkat lokal dengan keunikan masing - masing perlu 
dilakukan. Peneltian ini bertujuan untuk menguraikan kolaborasi pencegahan dan penanggulangan covid 19 di Kota Baubau, khususnya di Kelurahan Wajo dan Kelurahan Lakologou. Kelurahan Wajo dipilih karena perwakilan kelurahan di pusat Kota Baubau, juga menjadi pemenang pertama perlombaan kampung tangguh yang dilaksanakan Kepolisian Kota Baubau, sedangkan Kelurahan Lakologou adalah pemenang kedua, sekaligus menjadi perwakilan kelurahan yang lokasinya jauh dari pusat Kota Baubau.

\section{Metode}

Penelitian kolaborasi pencegahan dan penanggulangan covid di Kota Baubau ini menggunakan desain kualitatif, alasannya agar mendapatkan penjelasan komprehensif dan mendalam. Sedangkan pendekatan penelitian yang digunakan pendekatan deskriptif berupa kata - kata tertulis atau lisan masyarakat Wajo dan Lakologou, Lurah Wajo dan Lakologou, anggota kepolisian sektor Wajo dan Lakologou serta pihak lain yang terlibat dalam kolaborasi menangani covid 19 tersebut. Penelitian ini juga bersifat interpretif, dimana beradasarkan pengamatan dan wawancara yang sudah dilakukan di atas serta dokumen proses kolaborasi pencegahan dan penanggulangan covid di Kota Baubau menginterpretasikan data sebagaimana dinyatakan (Anggito, 2018).

Sumber data primer didapat dari hasil wawancara terhadap informan, utamanya masyarakat dan Lurah Wajo dan Lakologou, juga berdasarkan pengamatan langsung di lapangan misalnya di posko penaanganan covid di Kelurahan Wajo dan Lakologou dan lumbung pangan di kedua kelurahan tersebut. Sedangkan data sekunder diperoleh hasil penelitian terdahulu dan dokumen laporan kegiatan kampong tangguh di kedua Kelurahan. Instrumen utama dalam penelitian ini adalah peneliti dimana peneliti secara bersama merencanakan, melaksanakan dan menyusun hasil penelitian kolaborasi pencegahan dan penanggulangan covid 19 di Kota Baubau. Teknik pengumpulan data adalah wawancara, pengamatan dan studi dokumentasi. Wawancara secara keseluruhan dilakukan pada Lurah Kelurahan Wajo dan Lakologou, masyarakat Kelurahan Wajo dan Lakologou, anggota kepolisan resort kota Baubau, staf dinas kecamatan Wolio dan Murhum, staf dinas kesehatan dan dinas sosial Kota Baubau. Semua hasil jawaban yang diperoleh dikumpulkan dan diidentifikasi, serta direduksi.

Hasil wawancara juga dibandingkan dengan hasil dengan pengamatan langsung dan dokumen atau ditriangulasi misalnya pernyataan Lurah Lakologou tentang lumbung pangan dikonfirmasi dengan pengamatan langsung peneliti dengan melihat langsung 
keberadaannya. Terakhir, terkait teknik analisis data dilakukan dengan cara menyiapkan transkripsi wawancara dan memilah data yang sudah didapatkan dari wawancara, pengamatan, studi dokumentasi dan triangulasi terkait kolaborasi penangan covid di Kota Baubau dengan model kampung tangguh sejauh ini. Selanjutnya kami peneliti, membangun konsep umum dan merefleksikan data dan makna secara keseluruhan sebagaimana sudah dijelaskan di atas. Terakhir kami menganalisis lebih detail dan memaknainya, semua merujuk pada pendapat Creswell (2014).

\section{Hasil dan Pembahasan}

\section{Kolaborasi di Kelurahan Wajo}

Kelurahan Wajo Kecamatan Murhum Kota Baubau sempat menjadi percontohan kampung tangguh yang digagas Kepolisian Resort Baubau. Kampung tangguh ini hasil kerjasama dengan berbagai pihak baik dari Pemerintah Daerah Kota Baubau dan mengupayakan penguatan strategi penanggulangan pandemi Covid-19 sesuai acuan nasional yaitu melaksanakan $3 \mathrm{~T}$ yaitu testing, tracing dan treatment. Keseimbangan antara peran masyarakat dalam 3M dan pemerintah melalui Dinas Kesehatan dalam 3T, menjadi satu kata kunci yang bagus. Posko kampung tangguh di Kelurahan Wajo ini diberi nama Posko Siolimbona. Kampung tangguh dilengkapi dengan pemeriksaan dimana didalamnya terdapat tenaga kesehatan yang bertugas untuk memeriksa masyarakat dengan berpakaian adat Buton. Semua ruang kosong dalam areal kampung tangguh dimanfaatkan sebaik mungkin. Di belakang posko dijadikan pelayanan posyandu. Sementara areal tanah kosong seluas puluhan meter dimanfaatkan dengan membudidayakan buah-buahan dan sayur mayur sebagai lumbung pangan. Di pojok paling belakang kampung Tangguh disiapkan satu bangunan khusus sebagai rumah sehat untuk isolasi mandiri bagi warga terkonfirmasi Covid-19.

Di sisi lain, dengan adanya kampung tangguh ini bukan hanya melawan Covid19, tapi juga menjaga keamanan dan ketertiban masyarakat dari hal negatif. Dibuatnya kampung tangguh ini juga menerapkan disiplin yang tinggi agar kesadaran yang datangnya benar-benar dari hati sehingga tercipta kampung yang tangguh dalam segala hal bukan hanya melawan Covid-19. Semua disiplin protokol kesehatan dijalankan. 


\section{Kolaborasi di Kelurahan Lakologou}

Dalam konteks Lakologou, pembangunan kampung tangguh, sebenarnya bukan seperti membangun bangunan baru, tetapi merupakan proses restrukturasi sistem yang telah ada di kampung. Kader dasa wisma telah terbiasa dalam pengelolaan lumbung pangan sehingga menyokong instalasi lumbung pangan kampung. Bidan, kader posyandu atau kader KB hanya ditambah ketrampilannya dalam menangani masalah covid-19. Tiga hal penting dalam kolaborasi yang dilakukan adalah kebersihan, ketahanan pangan, dan penanganan isolasi mandiri bagi yang terindikasi ODP covid 19. Kelurahan Lakologou dipilih sebagai perwakilan Kecamatan Kokalukuna karena dinilai lebih lengkap dan lebih siap untuk menjadi model kampung tangguh. Untuk ketahanan pangan, penekanannya pada budidaya tanaman seperti sayur-sayuran. Melalui kegiatan ini, masyarakat mendapatkan pengetahuan tentang budidaya sayur-sayuran. Sedangkan aspek kebersihan diantaranya tentang penerapan hidup bersih sesuai protokol kesehatan. Sedangkan isolasi mandiri adalah penanganan bagi orang yang disinyalir ODP covid 19. Atas prestasi ini, Kampung tangguh di Lakologou dibawah bimbingan Kapolsek telah memberikan teladan dan pendidikan yang baik untuk masyarakat. Disamping itu di dukung Babinsa, babinkammtibmas, pegawai kelurahan, dinas kesehatan, dinas informatika dan RW secara mandiri. Kedudukan kampung tangguh bukan membuat baru, tetapi lebih sebagai upaya memperkuat dan mensistemkan komponen yang telah ada sekaligus mengupgrade SDM agar compatible dengan ketangguhan yang dibangun. Kampung tangguh yang ada hanya melakukan tambal sulam dari yang telah ada.

Baik kampung tangguh Lakologu maupun di Kelurahan Wajo (Siolimbona) telah menjalankan atau membangun beberapa dimensi ketangguhan berdasarkan kolaborasi berbagai pihak dan berbasis masyarakat. Ketangguhan yang dimaksud adalah:

\section{a. Ketangguhan Ketertiban Dan Keamanan}

Dalam dimensi ini telah tersedia sejumlah fasilitas, seperti pengadaan POSKO terpadu yang berfungsi sebagai pusat pengendalian kegiatan. Posko di Lakologou masih ada meskipun tidak berfungsi lagi seperti pada saat Kampung Tangguh di tahun 2020. Namun di Kelurahan Wajo sama sekali tidak terlihat posko terpadu padahal diketahui bahwa Kelurahan Wajo adalah pemenang pertama di Kota Baubau dan posko tersebut tidak lagi berfungsi dalam menjaga keamanan maupun ketertiban sosial dalam rangka pencegahan Covid-19. Keberadaan posko atau check point hanya ada pada awal dan pada saat proses penilaian lomba. Keterangan pimpinan kampong tangguh Kelurahan Wajo 
antara lain telah menyediakan sarana Check Point berupa Posko Terpadu yang mereka sebut sebagai Posko Kampung Tangguh yang melibatkan Linmas, Karang Taruna, maupun unsur masyarakat lainnya yang didukung oleh TNI-Polri. Pihak kepolisian setempat yang dibantu oleh TNI dan masyarakat selalu waspada terhadap meningkatkan kasus Covid-19. Sejak dibentuknya Kampung Tangguh di kedua kelurahan, proses pencegahan Covid-19 di kelurahan pengelolaan lebih teroganisir. Telah dibuat struktur yang jelas akan setiap tugas dari para anggotanya, namun untuk Kelurahan Wajo dokumen tersebut tidak terlihat lagi.

Polres Baubau membentuk Unit Pengamanan Kampung (UPK) sebagai bagian dari ketangguhan keamanan. UPK berfokus pada upaya menekan laju penyebaran covid19 melalui pengendalian dengan melakukan screening, pembatasan pergerakan warga dan menciptakan kepatuhan masyarakat pada protokol kesehatan. Pada tahap pendataan \& pengorganisasian, Bhabinkamtibmas kepolisian bersama pilar kelurahan lainnya sebagai motor sedangkan pada tahap implementasi peran ini menjadi assesor problem solving. Kemampuan pos pemeriksaan yaitu komunikasi persuasif, targetnya adalah menciptakan banyak self care, kemudian pemetaan \& pengenalan kampung, targetnya adalah mampu menginventarisir sumber daya yang ada untuk kebutuhan bagaimana struktur yang dibutuhkan \& mendudukan masalah kampong.

b. Ketangguhan Informasi

Selain mencegah hoaks, informasi yang tangguh akan memberi rasa percaya masyarakat kepada pemerintah daerah Kota Baubau. Ketangguhan informasi merupakan ketangguhan utama yang juga dibangun dalam menghadapi Covid-19 Ada empat level media informasi yang dikelola kampung tangguh Kelurahan Lakologou maupuk Kelurahan Wajo. Pada level 4 diletakan sumber informasi umum, sehingga masyarakat tidak menjadikan rujukan utama sebelum diverifikasi oleh kader informasi.

Kedua Kampung Tangguh, memiliki kemampuan mengelola informasi dari untuk memberikan edukasi kepada masyarakat agar sadar terhadap dampak dari pandemi Covid-19. Pembuatan spanduk atapun posko pengaduan di kawasan Kelurahan Wajo dan Lakologou sebagai media sederhana tetapi paling tangguh untuk mengedalikan informasi pada saat chaos atau krisis yang tidak terganggu oleh hoaks. Di kedua kampong tangguh, khususnya pada tahun 2020 mengandalkan penggunakan media sosial. Pemerintah daerah menyadari informasi hoaks yang menyebar akan membentuk opini masyarakat yang bertolak belakang belakang dengan kenyataan. 


\section{c. Ketangguhan Psikologi}

Kelurahan Lakologou menjadi salah satu kelurahan yang sedikit memiliki kasus positif Covid-19. Hal tersebut tak lepas dari usaha keras dan ketangguhan psikologi warga setempat untuk mematuhi protokol kesehatan dan juga keaktifan kampong tangguh yang dibangun. Program kampung tangguh ini menjadi program dalam pemaksimalan pemutusan rantai penyebaran virus covid-19. Fasilitas yang ada di kedua kelurahan adalah memiliki posko kesehatan, lumbung pangan, ruang isolasi, dapur umum, tempat cuci tangan, penyediaan handsinitizer dan kawasan wajib bermasker. Sikap gotong royong antar warga memperkuat psikologi masyarakat dan menciptakan keyakinan bersama dalam mencegah dan mengatasi covid 19. Gotong-royong antara berbagai pihak yang terlibat merupakan bentuk solidaritas sosial yang terjadi dalam kehidupan masyarakat yang sudah lama ada, terutama bagi mereka yang membentuk komunitas. Di kedua kelurahan ini, dalam memenuhi syarat serta pengadaan fasilitas untuk membangun program Kampung Tangguh ini, pemerintah kelurahan membentuk tujuh satgas, yaitu satgas pangan, bansos, dapur umum, trasnportasi, kesehatan, keamanan, dan permasalahan. Selain itu, kegiatan dilanjutkan dengan membuat papan sedekah, penyemprotan disinfektan, dan pembagian masker untuk warga.

d. Ketangguhan Budaya

Paling tidak terdapat empat budaya yang dimiliki kampung tangguh selama pandemic di kedua kelurahan ini yakni budaya berbagi, mengingatkan sesama, menolong, dan toleransi. Bahkan di kedua Kelurahan ini menerapkan Prinsip PO-5 yaitu pobhincibhinciki kuli, pomamasiaka, poangka-angkataka, pomae-maeaka, dan popia-piara yang merupakan warisan budaya leluhur. Budaya berbagi ditunjukan langsung dengan besarnya sumbangan yang diberikan oleh warga yang mampu kepada sistem kampung tangguh. Gotong royong dan sistem yang transparan dan berkeadilan, mendapatkan respon baik di kedua kelurahan. Di Kelurahan Lakologou, terdapat 13 penyumbang dimana 10 diantaranya merupakan pribadi. Bahkan RW juga menyumbangkan uang kas sebesar Rp. 650.000.. Setelah dibangun sistem ketangguhan, maka membangkitkan budaya berbagi masyarakat. Mereka yang dulu menjadi beban sekarang menjadi bagian integral dari perang melawan Covid-19.

Berbagai upaya dalam rangka melakukan pencegahan dan penanggulangan penyebaran Covid-19 turut dilakukan Kota Baubau. Hal ini karena peran pemerintah daerah sangat penting dalam upaya melawan pandemi COVID-19. Daerah dapat 
melaksanakan kewenangan sebesar-besarnya secara sendiri atau berkolaborasi dengan pihak terkait (Ginanjar, 2021). Salah satunya dengan menciptakan kawasan kampung tangguh, Kampung Tangguh di Kota Baubau diinisiasi pihak kepolisian. Namun, program Kampung Tangguh tidak akan berjalan maksimal tanpa semangat kerjasama dari masyarakat. Pemerintah Kelurahan di Baubau sangat mengapresiasi program Kampung Tangguh karena Covid-19 berpotensi menimbulkan kematian. Kampung Tangguh yang diprogramkan pihak kepolisian juga sebagai cerminan bahwa polisi memang hadir sebagai pengayom masyarakat, Kepolisian bersama masyarakat di Kelurahan sangat mendukung program ini.

Temuan penelitian ini sejalan dengan Wulandari (2019) yang menemukan bahwa dalam kolaborasi diaali dilakukan dengan dialog dan pertemuan tatap-muka yang dilakukan dimana dengan seringnya pertemuan maka terbangun kepercayaan dan terdapat kemauan menyampaikan pendapat, informasi serta saling membantu menyelesaikan permasalahan serta disamping itu terdapat komitmen dimana aktor yang terlibat mampu konsisten dan bertanggung jawab terhadap tugas dan diikuti kesadaran bahwa adanya tugas dan peran yang harus dijalankan masing-masing pihak. Kondisi tersebut berdampak adanya peningkatan pemberdayaan dan kapasitas kolaborasi dan masing - masing pihak yang terlibat. Temuan penelitian Kolaborasi pencegahan dan penanganan covid di Kota Baubau juga sejalan dengan Mujahiddin (2021) yang meneliti pengembangan desa tangguh Covid-19 berbasis pemberdayaan kelompok tani. Dimana pengembangan tersebut mampu meningkatkan pemahaman kelompok tani terkait. Termasuk tentang teknis pembentukan dan peningkatan kapasitas manajemen bisnis pertanian berbasis sociopreneurship. Keterlibatan multistakeholder mendukung terwujudnya desa tangguh Covid-19 serta mendukung pengembangan manajemen bisnis tani berbasis sociopreneurship. Masing - masing pihak menjalankan peran dan fungsinya.

Kolaborasi yang terjadi menunjukkan kapasitas untuk melakukan tindakan bersama. Sebagaimana muara yang diinginkan dari kolaborasi adalah mampu menghasilkan outcome yang dikehendaki bersama yang tidak dapat dicapai secar individu. Hal ini dikarenakan proses kolaborasi akan melibatkan kegiatan kooperatif untuk meningkatkan kapasitas diri dan banyak orang untuk mencapai tujuan bersama. Kolaborasi yang ada menghasilkan kapasitas baru bagi masing- masing aktor untuk bertindak bersama yang dilakukan dalam kurun waktu tertentu. Kapasitas yang ada merupakan kombinasi dari prosedur dan kesepakatan institusi, kepeimpinan, pengetahuan 
dan sumber daya yang dimiliki (Emerson, Kirk., 2012). Rachim (2020) dan Cahyono (2020) menyatakan pada dasarnya kapasitas untuk melakukan tindakan bersama merupakan hal krusial dan merupakan tantangan utama kolaborasi karena selalu terdapat perbedaan karakteristik dan kekuatan antar aktor. Terdapat pengaruh yang muncul dari komponen. masing - masing dan ini menggerakan prinsip dan motivasi bersama. Penelitian ini sekaligus memperkuat pernyataan bahwa pola kolaborasi tidak hanya cukup mensinergikan pemerintah, swasta dan LSM , tetapi unsur lain dimana dalam hal ini masyarakat menjadi penting. Ditemukan pemangku kepentingan lain yang berperan penting tetapi tidak terpetakan dengan konsep analisis pemangku kepentingan penta helix yaitu masyarakat itu sendiri sebagai terdampak utama dalam pandemic covid -19 . Masyarakat merupakan bagian penting dari tahapan pengelolaan kolaborasi pencegahan dan penanganan pandemi, sebab sebelum pihak lainnya terlibat mereka sudah melakukan tindakan yang perlu dipersiapkan

Masalah utama kolaborasi pencegahan dan penanggulangan covid 19 dengan pola kampong tangguh adalah pemeliharaan dan Keberlanjutan. Masalah ini sudah diingatkan Febrian (2016) yang menyatakan permasalahan yang terjadi dalam konsep kolaborasi adalah kurang berjalannya sistem contexs, leadership, dan dinamika kolaborasi yang terjadi yaitu kondisi yang tidak mendukung semua pihak sehingga menuju terjadinya ego sektoral. Konsep kolaborasi memang bisa sebagai alternatif mewujudkan percepatan implementasi program dan kegiatan tetapi seringkali dinamika dalam kolaborasi termasuk kepemimpinan dan konteks system dimana kolaborasi berjalan, sama sekali tidak mendukung pemeliharaan atau keberlanjutan pencapaian kolaborasi yang sudah dicapai. Menurut Rachim (2020), kolaborasi yang efektif dan berkesinambungan mensyaratkan pemimpinnya untuk memiliki keterampilan dan kesediaan untuk masuk ke kemitraan yang kuat. Ketergantungan pada prosedur secara berlebihan dan sikap egosektoral justru akan menghambat kolaborasi dan tidak mendukung peningkatan dan keberlanjutan kolaborasi.

Sebagai sistem, kampung tangguh kedua kelurahan sebenarnya juga sempat melakukan pemeliharaan agar mampu menjaga konsistensi menghadapi Covid-19. Pemeliharaan yang dimaksud terdiri dari 3 aktifitas pertama pendampingan oleh para pihak seperti pemerintah daerah melalui lurah dan kepala dusun, atau instrument lainnya, termasuk kepolisian dan TNI. Kedua, adanya supervisi oleh perguruan tinggi dan LSM dan ketiga membangun sistem informasi. Pendampingan di kedua kelurahan tersebut 
dilakukan oleh dinas-dinas dari pemerintah Kota Baubau yang sesuai dengan tupoksi mereka. Contohnya informasi kampung tangguh disinergiskan dengan strategi pembangunan informasi Kota Baubau untuk memperkuat proses pembangunan wilayahnya masing-masing. Demikian juga dengan ketangguhan kesehatan, dibantu dinas kesehatan dan menjadikan kampung tangguh sebagai bagian dari program kesehatan sekaligus intrumen program mereka. Pengembangan lumbung pangan disinergikan dengan program rutin dinas ketahanan pangan dan dinas pertanian Kota Baubau sebagai bagian dari program pembangunan cadangan pangan, distribusi pangan, juga promosi kesehatan pangan. Di Kelurahan Lakologou, sampai hari ini lumbung pangan masih ada sehingga dapat digunakan untuk bercocok tanam bagi masyarakat, sedangkan lumbung pangan yang dimiliki oleh kampung tangguh Kelurahan Wajo sudah tidak lagi ada karena lahan yang digunakan untuk lumbung pangan sudah diambil alih oleh pemilik tanah.

Supervisi oleh perguruan tinggi atau lembaga sosial kemasyarakatan sangat membantu meskipun sifatnya tidak bisa massif dan sekuat dinas atau lembaga pemerintahan Kota Baubau. Namun demikian lembaga-lembaga tersebut dapat mempercepat proses pertumbuhan kampung tangguh karena sebenarnya kampung tangguh juga dipersiapkan untuk pemulihan ekonomi paska Covid-19. Maintenance kampung tangguh tidak hanya menjaga agar kampung tangguh selalun siap untuk menghadapi Covid-19, tetapi juga sebagai pondasi untuk membangun pemulihan ekonomi kemudian. Ketiga, terkait sistem informasi kampung tangguh. sebenarnya, harus dibuat sebelum gerakan kampung tangguh diluncurkan, tetapi karena Covid-19 menyebar begitu cepat, maka sistem informasi ini dibuat seadanya, dan tidak bisa digunakan untuk evaluasi kampung tangguh.

Jadi, terkait pemeliharaan atau maintenance terlihat sedikit perbedaan di dua kelurahan. Di Kelurahan Wajo lokasi lumbung pangan hanya berstatus pinjam pakai sehingga setelah selesai program kampung tangguh, maka pemilik tanah mengambilkan kembali. Berbeda dengan lokasi lumbung pangan kampung di Kelurahan Lakologu yang masih ada hingga kini. sehingga sebenarnya cukup layak program kampung tangguhnya dipertahankan meskipun pandemi telah usai. Tim Kampung Tangguh Beriman maupun Siolimbona tidak sekedar bertugas mengontrol setiap aktifitas warga yang keluar masuk di kelurahan. Keberadaan Kampung Tangguh, juga memberikan kesempatan banyak proses belajar seperti membuat desinfektan dan sejumlah keterampilan lainnya yang berkaitan dengan penanganan dan pencegahan COVID-19. Kemampuan dan kerjasama 
yang telah dimiliki sebelum adanya pandemic oleh Kelurahan Lakologou ditambah proses peningkatan kapasitas selama pelaksanaan kampong tangguh menunjukkan mereka lebih memiliki kekuatan dan kesempatan untuk memberlanjutkan program kampong tangguh dan bias bermanfaat luas ke depan.

Terlepas dari kekurangan di atas, kolaborasi dalam pencegahan dan penanggulangan covid di Baubau faktanya telah mampu menghadirkan kontributor baru dalam pengelolaan pembangunan. Dan tidak bersifat eksklusif pemerintah saja. Kolaborasi yang tercipta selama pandemi covid khususnya di tahun 2020 mampu melahirkan modal sosial dalam artian kemampuan para aktor untuk mengorganisir dan mengkordinasikan tindakan ke arah pencapaian tujuan. Unsur modal sosial yang dimaksud yaitu saling kepercayaan dan kelembagaan yang terbangun Terakhir kolaborasi mengkondisikan keberlanjutan program. Ini dikarenakan selama penanganan covid 19, utamanya di kelurahan Lakologou kolaborasi menciptakan kepekaan mengidentifikasi kebutuhan/masalah, kepekaan menyelesaikan masalah secara bersama, rasa memiliki terhadap hasil dan rasa bertanggung jawab atas pencapaian. Disamping ketangguhan, terdapat pula pemeliharaan atau sistem maintenance. Pemeliharaan atau maintenance kampong tangguh yang ada di Kelurahan Lakologou memiliki karakteristik yang lebih kuat dan lebih memiliki poteensi keberlanjutan dibanding yang ada di Kelurahan Wajo.

Kolaborasi pencegahan dan penanggulangan Covid- 19 di Kota Baubau, khusunya di dua kelurahan ini, mestinya bisa merubah pola masyarakat untuk tetap peduli dan menjaga kampong tangguh dan tetap melaksanakan protokol kesehatan. Kampung tangguh dengan ketangguhan ketertiban dan keamanan, ketangguhan informasi, ketangguhan psikologi dan ketangguhan budaya serta pemeliharaan atau system amaintenance semestinya diperthankan bahkan ditingkatkan bagi kepentingan kepentingan lain ke depan. Dengan kohesivitas social yang tinggi melalui pola kolaborasi maka banyak program dan kegiatan pemerintah dapat dilakukan dan mencapai tujuan.

Interaksi antar pelaku memang perlu berlangsung maksimal. Nasrulhaq (2020) sendiri mengingatkan pentingnya aspek komunikasi bagi kuatnya kohesivitas. Efektifitas komunikasi yang terjalin dapat berdampak pada penguatan interaksi berbasis kolaborasi. Komunikasi multiarah menyiratkan bahwa dalam kolaborasi terdapat sesuatu yang lebih dari hubungan antar pelaku. Dalam proses ini sekaligus terdapat curah pendapat dan berbagi informasi. Disamping itu, Nasrulhaq (2020) juga mengatakan kapasitas kolaborasi dapat dilihat dari unsur sumberdaya yang terbagi. Maksudnya agar setiap 
pelaku dapat saling menguatkan kelemahan dan kelebihan. Ini sejalan dengan Lee, S.-Y \& Whitford (2013) yang mengatakan kinerja organisasi banyak dipengaruhi oleh kapasitas sumberdaya yang dimiliki. Kolaborasi yang sudah dijadikan strategi dalam pencegahan dan penanggulangan covid di Kota Baubau memang harus memperhatikan sumber daya dalam rangka penguatan kolaborasi. Tatap muka, rapat, pertemuan dan forum kolaborasi seharusnya telah menjadi milik bersama para pelaku kolaborasi dan menjadi media pembagi sumberdaya. Sedangkan Astuti Umar \& Burhanuddin (2019) menekankan aspek komitmen sebagai komponen yang vital dalam proses kolaborasi dan keberlanjutan. Komitmen berhubungan kuat dengan motivasi hakiki para pelaku dalam kolaborasi. Dalam konteks penelitian ini, semua pihak seharusnya memiliki komitmen kuat menyelesaikan tugas dan memberlanjutkan kolaborasi berdasarkan kesepakatan awal. Komitmen bergantung pada pengakuan bersama yang merupakan cara terbaik untuk mau menghormati dan prespektif dan kepentingan actor lain mampu memperkuat keterlibatan antar aktor.

Sigit Sepriandi (2019) mengungkapkan masalah bagi kolaborasi adalah faktor kultural. Maksudnya berkaitan erat dengan budaya kerja yang dilakukan oleh sumber daya manusia yang terlibat. Pemimpin dan fasilitator harus mencontohkan budaya komitmen untuk belajar dan mengadopsi keterampilan kolaboratif seperti kemampuan mendengarkan aktif dan memastikan bahwa semua peserta didengarkan dan diperlakukan secara adil, Menurut mereka, faktor kultural menjadi faktor penghambat bagi kolaborasi dikarenakan sumber daya yang dikerahkan belum mampu melaksanakan tugas sebagaimana mestinya. Meskipun keterlibatan seluruh pemangku kepentingan dalam pertemuan juga sudah diusahakan untuk menerima masukan dalam pelaksanaan kolaborasi tersebut. Namun dalam implementasi di lapangannya memang masih menjadi hal yang sulit dilakukan. Selain itu kemampuan untuk menerima keterlibatan pemangku kepentingan di luar pemerintahan juga kurang diberikan ruang untuk ikut berpartisipasi secara aktif. Sigit Sepriandi (2019) menambahkan faktor kepentingan pemerintah juga menghambat jalannya kolaborasi yang dibangun. Ini beririsan dengan temuan dalam uraian di atas, bahwa kepentingan egosoktoral dan dominasi pemerintah untuk menyelesaikan masalah publik secara sendiri dengan berbagai alasan. Misalnya terkait tumpang tindih kewenangan pada siapa sebenarnya penanganan suatu masalah itu mestinya di atasi berdasarkan tugas pokok dan fungsi. Pemerintah secara kultural masih enggan berbagi peran dengan aktor lain dan sikap ini masih dipegang kuat oleh sebagian 
besar aparatur pemerintah baik di pusat maupun di daerah. Padahal dalam konteks penanganan covid 19 masyarakat dan pihak non-pemerintah dapat berpartisipasi aktif dalam berbagai bentuk kerelawanan (Elfi Quyumi, 2020). Pandemi COVID-19 merupakan masalah bersama (Marya Yenita Sitohang, Angga Sisca Rahadian, 2020)

Ardian Prabowo \& M. R. Khairul Muluk (2021) mengusulkan model dalam kolaborasi, pemerintah menyiapkan platform dan memfasilitasi kerjasama yang lebih kuat antara swasta dan masyarakat. Ini dimaksudkan agar mencapai kemajuan dan inovasi baru yang bertanggung jawab melalui governansi pemerintahan yang lebih kolaboratif. Sedangkan relasi pemerintah dengan komunitas ataupun masyarakat membutuhkan dua kegiatan yang vital termasuk bagi keberlanjutan yakni pola feedback dan instrument pendukungnya dan edukasi. Urgensi menyusun platform timbal balik dari komunitas atau masyarakat untuk pemerintah supaya mereka sebagai pelaksana maupun sasaran atau obyek program mampu memberikan input positif kepada pemerintah dalam kerangka perbaikan. Sedangkan aktivitas edukasi atau pengarahan diperlukan supaya menuntun pihak yang memiliki keterbatasan pengetahuan dan informasi.

Dengan demikian, untuk kepentingan kontinuitas kolaborasi dalam pencegahan dan penanggulangan maupun kebutuhan atau masalah publik lainnya dalam konsepsi kampung tangguh ataupun kerangka lainnya di Kota Baubau ke depan yang dikontrsuksi dengan pendekatan kolaborasi, untuk keberlanjutan dan pemeliharaan kolaborasi maka meski memperhatikan aspek komunikasi, pembagian sumberdaya, komitmen, kultural, kepentingan pemerintah, menyiapkan platform dan menyiapkan edukasi yang berkelanjutan bagi yang membutuhkan.

\section{Kesimpulan}

Kolaborasi berbasis masyarakat dalam pencegahan dan penanggulangan Covid19 di Kota Baubau sudah dilaksanakan khususnya di Kelurahan Wajo dan Lakologou melalui pembangunan kampung tangguh dengan memiliki ketangguhan ketertiban dan keamanan, ketangguhan informasi, ketangguhan psikologi dan ketangguhan budaya. Kolaborasi dalam pencegahan dan penanggulangan Covid- 19 di Kota Baubau memperkuat penjelasan bahwa kolaborasi bisa diaplikasikan pada sektor publik. Keterbatasan dari pemerintah sebagai pelayan dan manajer publik bagi mencapai hasil yang baik perlu melibatkan pihak lain. Dimana, kolaborasi dalam penanggulangan Covid19 yang dilakukan selain melibatkan masyarakat kelurahan juga melibatkan Pemerintah 
Kota Baubau (Dinas Kesehatan, Dinas Sosial, Pemerintah Kelurahan dan Kecamatan dan beberapa SKPD terkait lainnya), Polres Baubau, Dandim 1413 Buton, DPRD Kota Baubau dan BPBD.

\section{Daftar Pustaka}

Andriyani., L. (2020). Kolaborasi Pusat Dan Daerah Dalam Penanganan COVID- 19. Rajawali Pers.

Anggito, A. dan J. S. (2018). Metodologi Penelitian Kualitatif. CV. Jejak.

Ansell, C., \& Gash, A. (2008). Collaborative Governance in Theory and Practice. Journal of Public Administration Research and Theory, 18(4), 543-571.

Ardian Prabowo1, M. R. Khairul Muluk, A. H. (2021). Model Collaborative Governance Dalam Pembangunan Desa Pada Masa Covid-19: Studi Di Kabupaten Lampung Selatan. PUBLISIA: Jurnal Ilmu Administrasi Publik, 6(1), 15-31. http://jurnal.unmer.ac.id

Astuti Umar, Burhanuddin, N. (2019). Kolaborasi Aktor dalam Pembangunan Pariwisata Hutan Mangrove Tongke-Tongke Kabupaten Sinjai, Sulawesi Selatan. MATRA PEMBARUAN Jurnal Inovasi Kebijakan, 3(1). jurnal.kemendagri.go.id

Cahyono, A. S. (2020). Implementasi Model Collaborative Governance Dalam Penyelesaian Pandemi Covid-19. Jurnal Publiciana, 13(1).

Creswell, J. W. (2014). Penelitian Kualitatif \& Desain Riset. (Ketiga.). Pustaka Pelajar, Terjemahan.

Elfi Quyumi, M. A. (2020). Upaya Pencegahan Dengan Kepatuhan Dalam Pencegahan Penularan Covid-19 Pada Relawan Covid. JPH RECODE, 4(1), 81-87. http://ejournal.unair.ac.id/JPHRECODE.

Emerson, Kirk., T. N. \& S. B. (2012). Integrative Frame Work for Collaborative Governance. Journal of Administration Research and Theory, 22.

Febrian, R. A. (2016). Collaborative Governance Dalam Pembangunan Kawasan Perdesaan (Tinjauan Konsep dan Regulasi). WEDANA : Jurnal Pemerintahan, Politik Dan Birokrasi, 2(1).

Ginanjar, D. (2021). Peran Pemerintah Daerah Pada Penanganan COVID-19 1. Jurnal Politik Pemerintahan Dharma Praja, 13(1). http://ejournal.ipdn.ac.id

Haryono, N. (2012). Jejaring Untuk Membangun Kolaborasi Sektor Publik. Jejaring Administrasi Publik, 4(1). 
Lee, S.-Y., \& Whitford, A. B. (2013). Assessing the Effects of Organizational Resources on Public Agency Performance: Evidence from the US Federal Government. Journal of Public Administration Research and Theory, 23(3), 687-712.

Marya Yenita Sitohang, Angga Sisca Rahadian, P. P. (2020). Inisiatif Masyarakat Indonesia Di Masa Awal Pandemi Covid-19: Sebuah Upaya Pembangunan Kesehatan. Jurnal Kependudukan Indonesia Edisi Khusus Demografi Dan COVID, 33-38.

Mujahiddin, S. S. dan. (2021). Desa Tangguh Covid-19 Melalui Pemberdayaan Kelompok Tani Berbasis Sociopreneurship Di Desa Sekoci Kabupaten Langkat. Jurnal Abdi Mas TPB, 3(1), 85-93. www.abdimastpb.unram.ac.id

Nasrulhaq. (2020). Nilai Dasar Collaborative Governance Dalam Studi Kebijakan Publik. Kolaborasi : Jurnal Administrasi Publik, 6(3). http://journal.unismuh.ac.id/

Ni Made Dwi Arisanti, I. W. S. (2020). Penanganan Pandemi Covid-19: Kolaborasi Pemerintah Kabupaten Bersama Knpi Gianyar Di Kabupaten Gianyar, Ba. Spirit Publik: Jurnal Administrasi Publik. Universitas Sebelar Maret, 15(2).

Rachim, R. S. A. H. W. A. (2020). Collaborative Governance dalam Perspektif Administrasi Publik. Universitas Diponegoro Press.

Salman, D. (2004). Kolaborasi antar Pelaku Dalam Pembangunan Ekonomi Wilayah ” Makalah disampaikan dalam Semiloka Perencanaan Pembangunan Ekonomi Wilayah Berbasis Kependudukan.

Setneg. (2009). Undang-Undang Nomor 36 Tahun 2009 tentang Kesehatan.

Sigit Sepriandi, R. H. (2019). Faktor-Faktor yang Mempengaruhi Collaborative Governance dalam Penanganan Pekerja Migran Bermasalah di Kota Tanjungpinang Factors Affecting Collaborative Governance in Handling Deprived Migrant Workers in Tanjungpinang City. JPPUMA: Jurnal Ilmu Pemerintahan Dan Sosial Politik UMA (Journal of Governance and Political Social UMA), 7(1), 80-91.

Sudarmo. (2015). Menuju Model Resolusi Konflik Berbasis Governance: Memuat Pengalaman Penelitian Lapangan Tentang Isu Pedagang Kaki Lima Dan Konflik Antar Kelompok. Sebelas Maret University Press.

Wulandari, F. (2019). Kolaborasi organisasi terhadap perlindungan dan pelayanan publik (studi kasus penyandang disabilitas di kabupaten bone). Universitas Muhammadiyah Makassar. 